\title{
Developing the Tourism Industry of Lahat Regency through Its Culinary Dish
}

\author{
Muhammad Arif Ramadhan \\ Sekolah Tinggi Pariwisata Trisakti, Jakarta, Indonesia \\ Email: ardianmuhammadariframadhan@gmail.com
}

\begin{abstract}
The purpose of this research is to investigate whether the culinary of Lahat Regency such as Jekhuk, Tebu Telok, Jamur Gerigit and Terung Kerutuk is able to be promoted to boost the tourism industry in Lahat Regency, South Sumatra. This research design is a case study that involves three experts of the heritage, culture, culinary and language of the Lahat Region and three restaurants located in Lahat Regency. An interview was conducted to collect data and excerpts of the interview was analysed. It was found that these traditional foods were able to be promoted for the tourism industry and later on developed for further packaging.
\end{abstract}

Keywords-Culinary; Traditional Food; Tourism; Lahat.

\section{INTRODUCTION}

This paper aims to explore and highlight the result of analsying and investigating the specialty culinary of Lahat Regency, South Sumatra in developing its tourism industry. Specifically in finding out whether these culinary is able to boost the tourism industry. The Regency of Lahat is one of those located in South Sumatra Province in which is the flagship in the tourism sector.

\section{A. Background}

Lahat Regency does have a lot of waterfalls, there are approximately 126 waterfalls, but only 15 which can be visited. The distance from Palembang City to Lahat Regency is approximately $250 \mathrm{~km}$. To reach Lahat Regency, it takes 5 to 6 hours on the way. The geographical condition of Lahat Regency lies between 3.25 degrees to 4.15 degrees in the south latitude, and 102.37 degrees up to 103.45 degrees at the east longitude. Lahat Regency covers an area of 4,361.83 km2. Furthemore, Lahat Regency has regional boundaries such as the following:

North: with Muara Enim and Musi Rawas districts

South: with Pagaralam City and South Bengkulu Regency of Bengkulu Province

East: Muara Enim Regency

West side: Regency of Empat Lawang

Based on the furthest distance from the capital of Lahat Regency to the capital District is Tanjung Sakti Pumu a subdistrict that is as far as $112.00 \mathrm{~km}$. While the closest distance from the capital of Lahat Regency to the district capital is Pulau Pinang Subdistrict. Lahat Regency actually consists of only 7 sub-districts namely Lahat, Kikim, Kota Agung, Jarai, Tanjung Sakti, Pulau Pinang and Merapi. However, after the expansion of the regions, the number of sub-districts in Lahat regency increased to 22 districts. Until 2014, Lahat District consists of 22 sub-districts, 17 sub-districts, 360 villages with definitive status [8].

The Vision of Lahat Regency for the year of 2014-2018 are: "Mewujudkan Lahat BANGKIT 2018" in English is Establishing the Rise of Lahat. 'Lahat Bangkit' consists of Self-Reliance, Safety, Comfort, 'Gotong Royong'-working as a team, Creativity, Innovation, and Leadership. On the other hand the Mission of Lahat Regency for the year of 2014-2018 are: Creating a Democracy, Justice, and Accountabilty of the Government System; Establishing the Civil Society (Productive, Independent, Mutual, Ethical, and Environmentally Friendly).The achievement of a formidable Economic Order Vision is a series of sentences that express the ideals or dreams of an organization to be achieved in the future. 
The Vision of Culture and Tourism Office of Lahat Regency is "The Establishment of Culture, Art and Tourism of a safe, comfortable, creative, innovative and a leading Lahat Regency in South Sumatera Province 2018". Whilst the mission is to achieve the vision . Specifically, the mission is what steps and strategic to achieve the vision of the Culture and Tourism Office of Lahat Regency. Hence, the formulation of the mission is a to establish an organization that is able to produce quality products and services that meet the needs, desires and expectations of customers.

To achieve the Vision of the Year 2014-2018, the strategies taken are as follows. Those are to establish the mission of the Department of Culture and Tourism of Lahat Regency, namely: Improving the Quality and Quantity Creatively; Being Innovative and Keeping and Preserving Traditional Culture Art and Local Wisdom.

Specifically, the missions are in developing the Potential of an Eco-Friendly Tourism Object, within easy reach and creating a sense of security and comfort; improving human resources to create innovative and qualified tourism; and improving the promotion and marketing of tourism objects and cultural arts creatively and innovatively through exhibition, print and electronic media to attract domestic and foreign tourists; and achieving the quality, the accountability and the performance of based planning, budgeting and reporting

\section{RESEARCH PROBLEM}

However, based on the statistics of South Sumatra Tourism, little is found about the development of tourism industry of Lahat Regency. There are many tourism objects, culture and heritage of Lahat Regency that is not yet known due to several issues but manly lack of promotion and exposure outside the South Sumatra Province. Hence, this research found a solution to conduct promotion effectively and efficiently by developing a project plan exposing the culinary dishes of Lahat Regency which is vital for the development of the welfare of the Lahat Regency, its government and its community. It is the community and the people of Lahat Regency that absorbs the maximum benefit of this research. Not only that the culinary of Lahat Regency is recognised worldwide moreover the community is able to develop their own home industry. Additionally, these culinary attracts tourists to visit Lahat Regency in which increases the capital tourism of Lahat Regency.

There has been several research about identifying tradional food and establishing them as the commodity for tourism industry. However, these research were conducted in other regions. Firstly, a research conducted by [2] documented the variety of traditional foods of Ciamis Regency, using a descriptive research design and qualitative approach. The data were collected through interviews and observation. The result of this research concluded from a geographical perspective stating that the tradisional food of Ciamis Regency is developed due to its geographical factors - the availability of food source in the environment. Furthermore, there has not been much change in its culinary only in the way it is prepared.

Secondly, a research conducted by [2] focused on a specific dish of Bataknese called 'Naniura'. The main ingredient is fish in which is not cooked but heavily dressed with traditional herbes. In this reseach, it proposed 'Naniura' to be promoted as an h'ordeuvre through cooking demonstation, advirtisements, brochures and the internet

Finally, there is one research conducted in Lahat Regency, yet focusing in economic growth and regency potential of Lahat Regency, using Shift Share and Typology Klassen Location Quotient (LQ) analyzer, Growth Ratio Model (GRM), Overlay [6].

In this research we investigate the tourism industry of Lahat Regency through its culinary dishes which could significantly boost the economy infrastructure of the government of Lahat Regency and its people. We need to find out whether culinary industry of Lahat is able to support the tourism industy. The researcher attempted in achieving the objectives by observing and interviewing a native of Lahat in his knowledge of Lahat culinary. This research scopes to the dishes that is able to be processed in a form of cans. Those dishes are 'Jekhuk', 'Tebu Telok', 'Jamur Gerigit', and 'Terung Kerutuk'.

The next sections will focus on the literature review, material and methodology, and results and discussions. 


\section{III.LITERATURE REVIEW}

\section{A. Previous Research}

The research conducted by [3] is similar to the conduct of this research. Both are attempting in developing the traditional food of the local community to attract tourists visits to the region. However, unlike Okech which depicts a personal experiences, in this research, it attempts to involve observing and obtainning the experiences of a local community member in developing local cuisine. The significant finding of Okech research is that in the promotion of the culinary of Kenya, the foods still uses food names that cater the needs of the westerner instead of using the local names which can be a good tool for food promotion. For the positive sake of the culinary of Lahat Regency, the local names are maintained as a way to promote local heritage such as language and culture.

Unlike [3], [5] used analytical strategy and SWOT approach in developing food industry. The result of SWOT analysis result in four strategies which support in developing the food promoted for tourism in Padang region. The four strategies are strength-opportunities strategy; strength-threats strategy; weakness-opportunities strategy; and weaness-threats strategy. However, the outcome of this strategy would be more comprehensive if the local community member together with expert in food technology marketing is involved to reach the best objective in promoting the local culinary.

Similar to [4], [5] also developed a traditional food of the local to as a way to support the tourism of Semarang City. However, unlike the research design is survey using quantitative descriptive research design with survey approach located at the Central Souvenir Shops of Semarang City which aims in distributing the tourists visiting the place. However, in the Lahat Regency, the destination of tourism is still developing and not many tourists visit the region. Hence, the research conducted in Lahat Regency applies a qualitative research design, specifically a case study by observing, conducting interview to a local member of Lahat Regency in an attempt to develop the culinary of Lahat Regency as a way to boost the tourism industry in the Lahat Regency, South Sumatra.

\section{B. The Culinary of Lahat Regency}

\section{Jekhuk}

The main ingredient of this dish is catfish. It is a fermented catfish which was previously coated with salt and sugar kept in jars for a minimum of three days. The way to cook this is by saute the fermented fish with little bit of oil.

\section{Tebu Telok}

The main ingredient of Tebu Telok or known for Saccharum edule a kind of asparagus of the east. The way to cook this is by saute the tebu telok with red onion, garlic, salt and pepper. This type of vegetable is found in the Regency of Lahat.

\section{Jamur Gerigit}

Jamur Gerigit is a type of mushroom that grows on tree branches. It is usually cooked with light coconut milk and saute with red onion and garlic.

\section{Terung Kerutuk}

The main ingredient of this dish is round green eggplants which are fairly small. It is usually cooked with smoked fish.

\section{A. Research Design}

\section{IV.METHODS}

Ethnographic design is the design used for this study. Where, Ethnographic Design is a qualitative research procedure for describing, analyzing, and interpreting communities with similar behaviors, beliefs, and languages that evolve over time. [7]. Ethnography is done when studying a group and giving understanding of a larger problem. Ethnography is also done when someone has a community that has the same behavior to learn together for some time and develops value, trust, and 
language [7]. One type of ethnography used in this study is case study. The case study is an in-depth exploration of a system that is limited based on extensive data collection [7].

\section{B. Sample and Population}

The sample and population are those who volunteered in this research. Three experts of the heritage, culture, culinary and language of the Lahat Region and three resturants located in the Lahat Regency.

\section{Data}

Due to etnography type of research, specifically a case study, the data was collected by conducting interview to several natives of Lahat Region that has expertise in the heritage, culture, culinary and language of Lahat. Furthermore, three restaurants located in Lahat Regency were interviewed. [7]. Additionally, these data were then documented and their excerpts were analysed.

\section{Methods}

There are also steps that were taken be done in conducting this study were among others identifying the purpsoe and the type of research design, in this case- a case study of the development of Lahat Culinary due to the problem of the research is to investigate the possibility of developing the culinary of Lahat Region to support the its tourism industry. The next step is to obtain a consent from the expertise and the restaurants that were interviewed. Their excerpts were analysed, summarised and intrepreted [7].

\section{E. Interview}

The questions that were delivered are as follows; for the experts are whether these traditional foods are found in the restaurants in Lahat Region; whether these traditional foods are found in other regencies; whether these traditional foods are often cooked in the households; whether possible to develop and preserve these traditional foods in a form of cans; and whether these traditional foods can attract tourists.

\section{F. Evaluation}

Based on three studies on the framework of thought [7] the evaluations conducted in this study include the descriptions; evaluation of data patterns; and which are followed by interpolation procedures. In this study, the evaluation involved expertise of heritage, culture, culinary and language of Lahat Region together with three owners of restaurants located in Lahat Regency.

\section{A. Result}

\section{RESULT AND DISCUSSION}

The three experts stated that is challenging to find the culinary of Lahat Region in restaurants accross Lahat Regency. This is in line with three main restaurants in Lahat Region, all of them did not sell any of the culinary of Lahat Region, even though they recognise them.

"Sangatlah sulit mendapatkan tebu telok, terung kerutuk, dan sejenisnya di restoranrestoran di kota Lahat".

"It is difficult to get tebu telok, terung kerutur, and other types of Lahatnese cuisine at restaurants in the cities of Lahat region".

"Kami tidak menjual makanan tebu telok, terung kerutuk apalagi jamur tikus, tidak pernah sama sekali."

"We do not sell tebu telok, terung kerutuk moreover jamur tikus, never at all'.

When asked about whether these traditional food can be found in other regions and whether they are often cooked in the household. All of them agree that these foods belong to the community of Lahat Region, and they strongly suggested that these food must be claimed by the government and 
state that it is the culinary of South Sumatra. Moreover, one way efficient way to promote these foods are by preserving them in cans and export them to neighbourhood countries, initially.

\section{B. Discussion}

In conducting this research there are some weakness found. Firstly, less sources were available to conduct the interview. Secondly, other local community member were not involved to enrich the investigation such as those who are from the young generations and most of all tourist that visited Lahat Regency. However, the culinary of Lahat Region are able to be promoted and developed as main attraction to boost tourism industry and more over it involves the community. This is in line with the three research that scoped on the traditional foods as discussed previously [1], [2], [3].

\section{VI.CONCLUSION}

It can be concluded that the government and the community are not working together to promote the culinary of Lahat Region. The traditional foods are not found in the restaurants accross the Lahat Regency. To develop and preserve these traditional foods need a standard mechanism in the process and in the marketing of these products. The source of sample and data are very limited. However, the aim of developing these traditional foods can be one means of boosting tourism industry and creating job opportunities for the community of Lahat Regency. It is strongly recommended that future research continues this study thoroughly and develop it into the government project for tourism industry.

Acknowledgement. This research is fully supported by Trisakti School of Tourism.

\section{REFERENCES}

ADRIANSYAH, Fitra, and M. Ec Soeratno. Analisis sektor dan subsektor potensial di Kabupaten Lahat Provinsi Sumatera Selatan, 1994-2003. Diss. Universitas Gadjah Mada, 2004.

Okech, Roselyne N. "Developing culinary tourism: The role of food as a cultural heritage in Kenya." Proceedings of the Second International Conference on Global Business, Economics, Finance and Social Sciences (GB14Chennai Conference). Chennai, India Paper ID: CF412. Retrieved from http://globalbizresearch. org/chennai_conference/pdf/pdf/ID_CF412_Formatted.pdf. 2014.

Manalu, Maria BF. "MEMPERKENALKAN NANIURA MAKANAN KHAS BATAK SEBAGAI HIDANGAN APPETIZER."

Makanan, Wisata. "STUDI POTENSI WISATA MAKANAN (FOOD TOURISM) DALAM PENGEMBANGAN PARIWISATA DI KOTA SEMARANG PROVINSI JAWA TENGAH."

Masduki, Aam. "MAKANAN TRADISIONAL DI KABUPATEN CIAMIS." Patanjala: Jurnal Penelitian Sejarah dan Budaya 4.2 (2012): 270-280.

Rosalina, Eka, and Afridian Wirahadi Ahmad. "ANALISA STRATEGI PENGEMBANGAN INDUSTRI MAKANAN TRADISIONAL MINANGKABAU BERBASIS PENDEKATAN SWOT." National Conference of Applied Engineering, Business and Information Technology, Politeknik Negeri Padang. ASCNI-Tech, 2016.

Creswell, John W., and Cheryl N. Poth. Qualitative inquiry and research design: Choosing among five approaches. Sage publications, 2017.

Profil lengkap Kabupaten Laat. http://www.fbrs14.com/2017/10/profil-lengkap-kabupaten-lahat.html Retrieved 22 Januari 2018 